\title{
Vulnerability to climate change and water management: hydropower generation in Brazil
}

\author{
M. A. V. Freitas ${ }^{1}$ \& J. L. S. Soito ${ }^{2}$ \\ ${ }^{1}$ International Virtual Institute of Global Changes, \\ Federal University of Rio de Janeiro, Brazil \\ ${ }^{2}$ Energy Planning Program, Federal University of Rio de Janeiro, Brazil
}

\begin{abstract}
Brazil has the largest reserve of surface water on the planet, approximately $19.4 \%$, of the world total, and one of the greatest hydraulic potentials. This does not however mean that it is in a comfortable position in terms of water availability and the location of consumptive and non-consumptive demand. In fact, around $90 \%$ of the water is to be found in the low demographic density hydrographic basins of the Amazonas and Tocantins rivers. Around $90 \%$ of the population relies on the remaining water resources.

Given the major role of hydroelectric plants in the Brazilian Electricity System, power generation in the country is highly dependent on the hydrologic regimes of the hydrographic basins. Given that there is regional imbalance in water availability - as evidenced by recurrent droughts in the North-eastern region and by the degradation of rivers and soil in the South East, the socioenvironmental risks to each region and the rapid increase in the demand for water and energy throughout country - new and existing hydroelectric energy plants are vulnerable, to a lesser or greater extent, to climate change.

The risk of future global climate change i.e. further warming of the planet, may alter the hydrologic cycle, and, consequently, the regime and hydric availability of the hydrologic cycle. In fact, differentiated changes in temperature lead to alterations in the range of atmospheric pressure and wind patterns. Changes in rainfall pattern are therefore to be expected.

The forecast rise in sea levels by 2099 indicates, in various scenarios of greenhouse gas emission, a range of between $18 \mathrm{~cm}$ and $59 \mathrm{~cm}$. The occurrence of the El Niño Southern Oscillation (ENSO) has been more frequent, longer and
\end{abstract}


more intense during the last twenty-three years, in relation to the previous 100 years.

There is, therefore, an urgent need for study focused on the forecast and analysis of the climatic vulnerability of electric energy generation in Brazil, particularly in terms of the expected inflow into hydroelectric reservoirs based on climate and hydrological forecasts. Such studies are fundamental for the definition of scenario in order to enable advance recognition of the risks to hydrology and, consequently, to energy systems

Keywords: vulnerability, climate change, water management, hydropower generation.

\section{Alterations to precipitation and rainfall patterns in South America}

According to studies from the IPH/UFRGS and IAG/USP the Centre-West, South and South Eastern regions have, since 1970, presented average flows approximately 30\% greater than the previous period (1940-1970). If this increase were to be permanent it would be possible to re-evaluate the firm energy of the plants, in other words, it would be possible, with the same installed capacity, to generate more energy with less risk of failure (Tucci et. al. 2002).

According to data from the IPCC (IPCC [10]), precipitation trends in South America between 1960 and 2000 reinforced the view that precipitation in the Prata basin was increasing, whilst decreasing in the Chilean and Peruvian Pacific watersheds. In the other areas the signs are unclear (see figure 1).

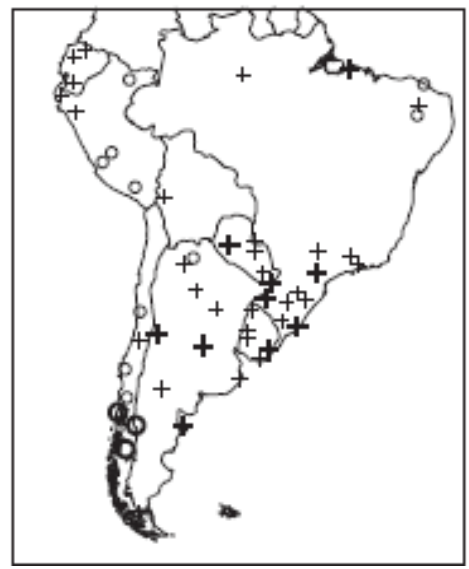

Figure 1: $\quad$ South America - Precipitation trends from 1960 to 2000. Note: the circles indicate and tendency towards reduction and crosses indicate a trend towards increase in rainfall. Highlighted symbols indicate a stronger trend. Source: IPCC, WG II [11]. 


\section{Conflicts, impacts and vulnerabilities of hydraulic generation}

The considerable diversity between the country's regions is an aggravating factor in the Brazilian experience of the use of hydraulic potential in relation to hydric availability. Whilst droughts recur in the northeast hinterland (sertão), the problem in the South-East is industrial and urban pollution, whilst in the South, agriculture and livestock are responsible for diffuse pollution of surface and underground water, which is difficult to control.

Set out below is a synthesis of the water resources available for various uses, highlighting vulnerability in terms of use and the principal conflicts over water use in three major hydro-graphic basins: the São Francisco, Paraná and Amazon river basins.

\subsection{The São Francisco basin}

The São Francisco basin has an installed hydroelectric generating capacity of around $10.23 \mathrm{GW}$, long term average outflow at the river mouth of $2850 \mathrm{~m}^{3} / \mathrm{s}$, a drainage area of $645,000 \mathrm{~km}^{2}$ and a population of over 15 million inhabitants.

It currently registers a demand for water for authorized irrigation of around $500 \mathrm{~m}^{3} / \mathrm{s}$, although the actual verified consumption does not exceed $150 \mathrm{~m}^{3} / \mathrm{s}$. This suggests a degree of over-estimation in the granting of irrigation rights, although some uncertainties exist. For 2025, it is possible to consider average authorized consumption of $335 \mathrm{~m}^{3} / \mathrm{s}$, which might suggest an impact on the generation of hydroelectricity of a median range of 300 to 900 MW depending on the location of the extraction of water from the São Francisco basin and the use to which the water is put (irrigation, human and animal supply.)

In figure 2 it is possible to identify the principal uses and potential conflicts in the use of water in the São Francisco basin.

\subsection{The Paraná Basin}

The Paraná basin is vitally important for the Brazilian electricity system. $50 \%$ of the country's installed capacity, which is operational in the country, is located there as is the Itaipu Hydroelectric Plant, which has a potency of 14,000 MW. This basin, however also has the greatest population density, which leads to several conflicts, urban and rural, over the use of the soil and water, which might undermine future utilization of the hydraulic potential and might also impose limitations on the generation of electricity at plants which have already been constructed and are in operation.

As such, it is necessary to be aware of the conflicts in the Paraná basin that give rise to vulnerability in terms of the generation of hydroelectric energy. This merits greater attention by the electricity industry and managers of the water, as the conflict might worsen in future whether as a result of demand for water resources or with the increase in the number of drought years caused by global warming. 


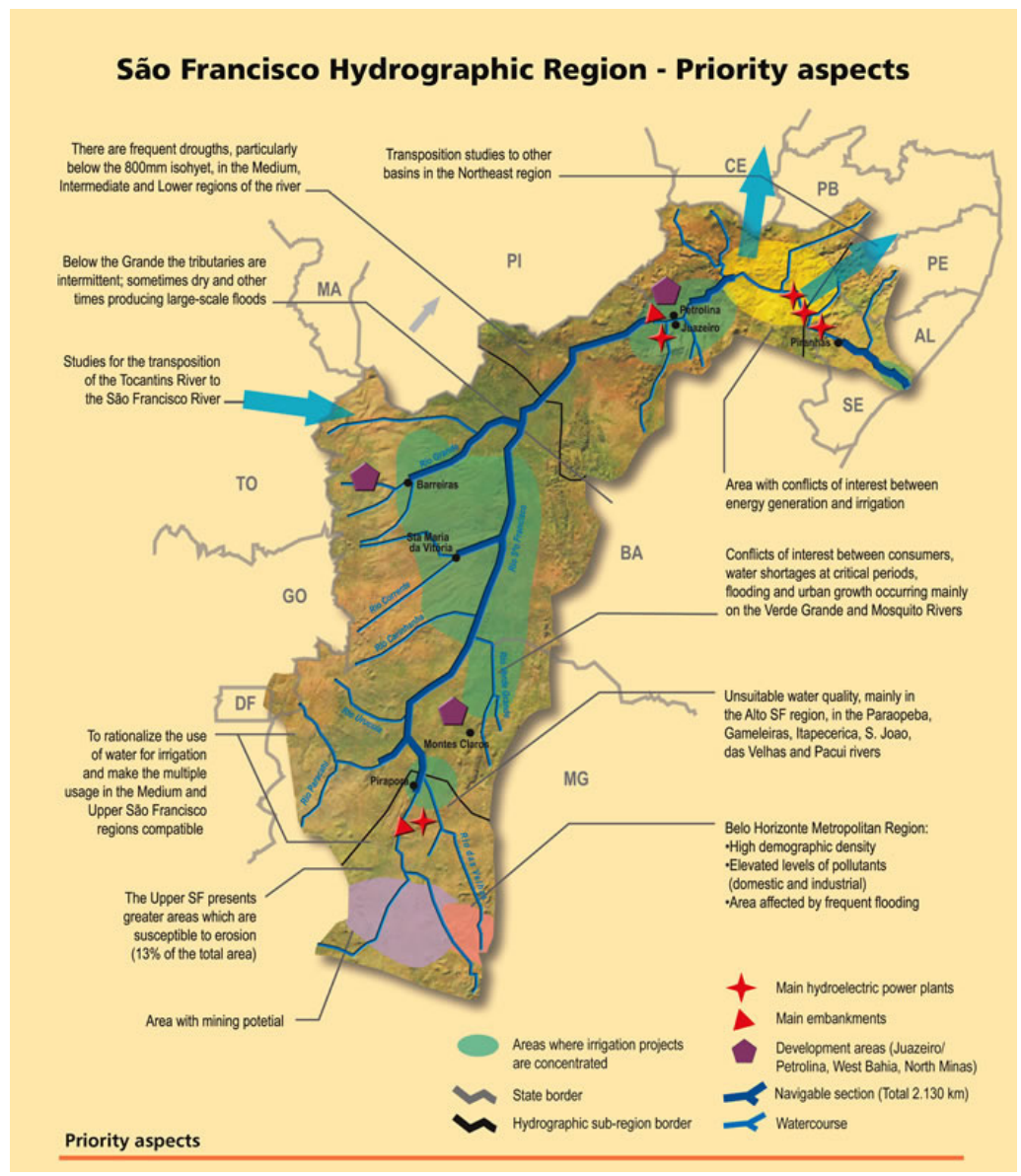

Figure 2: São Francisco Basin - principle conflicts over water use: ANA [2].

In terms of climate change, the main characteristic of the basin of the Paraná River is the risk of flooding with increased frequency during the years when there is anomalous warming of the Pacific Ocean, in other words, during the El Nino phenomenon. The cascades of hydroelectric plants in the basin have been have been used to regulate water availability and the management of extreme flood events. Cross-border integration is fundamental for improving the likelihood of success of such management. In other words, Brazil, Argentina, Paraguay, Uruguay and Bolivia should intensify the integration of their meteorology systems, water resources and hydroelectric energy in order to benefit from climatic variability (which has led to a significant increase in the availability of water), without, however, overlooking the protection of land and water use in the areas bordering on the dams. In relation to water potential, an 
increase of $30 \%$ in the average outflow of the Paraná River over a long period led to a considerable increase in hydraulic potential. Statistics for outflows between 1941-1971 and 1972-2000 set out an average variation of over 36\%.

\subsection{The Amazon Basin}

The continental Amazon Basin is the planet's largest hydro graphic basin, with a surface of approximately $6,100.000 \mathrm{~km}^{2}$. Situated in the inter-tropical zone, it receives annual average precipitation of $2460 \mathrm{~mm}$. The average outflow at the estuary of the Amazon River into the Atlantic Ocean is estimated to be 209.000 $\mathrm{m} 3 / \mathrm{s}$ (Molinier et al. [15]).

\subsubsection{Amazon Basin - hydric resources, vulnerability and climatic resources and principal conflicts over water use}

According to the results of the Hydrology and Geochemical project of the Amazon Basin (HiBAm) (Freitas, 2004 and Filizola, 2002), the Amazon basin is affected by the climatic variabilities of the ENSO (El Niño South Oscillation) that cause a significant decrease in precipitation (Aceituno [1]; Rao and Hada, 1987). The impact of this climatic variability on the hydrology of the Amazonas River and its principal tributaries has been studied by several authors (Marengo and Hastenrath [12]; Marengo [13]), but the results are partially invalid as they do not take into account the phenomenon of some hydraulic dams along the main flow of the Amazon River (Molinier et al. [14]). The impact of this climatic variability on erosion and the flux of material transported in the Amazon basin remain unknown.

We may highlight the following certainties and uncertainties in our knowledge of the hydro-meteorological regime of the Amazon basin:

Pluviometric variability is relatively well known in the Brazilian Amazon basin (Marengo and Hastenrath [12]; Roucou [18]), as well as in the Andean tropical zone (Aceituno [1]; Ronchail 1996, 1998 and 2002). There is, however, another zone which to date, has not been extensively studied, and is not well comprehended (between 5th and 25th parallels, latitude south), that is, a priori, linked to the oceanic signal, and which corresponds to the Amazon plains (Llanos) of Bolivia, Peru and the extreme west of Brazil.

The hydrological regimes are, nowadays well known in relation to the Bolivian and Brazilian Amazon River, thanks to the surveys carried out by the PHICAB and HiBAm programs (Roche et al. [17]; Molinier et al. [14, 15]). However there is practically no information regarding hydrology and erosion in the water courses within the Tropical Andean domain (Colombia, Ecuador and Peru), which is also an obstacle to the hydraulic modelling of the Amazon basin complex. Finally, the ENSO-hydrology report was minimally drawn upon in relation only to the Amazon River and its most important tributaries (Marengo [13]). The impact of climatic variability on hydrology in the Amazon basin complex is still relatively unknown.

In relation to global issues, the Amazon basin has an extremely important role in the climatic dynamics and the planet's hydrological cycle. The basin accounts 
for approximately $16 \%$ of the surface water stock and, consequently, provides a major contribution to the systems of rain and evapo-transpiration in South America and the world. Regional and global changes have led to alterations in the climate and soil use and in the hydrology of the region. Notably, transformations in the use of the soil with the conversion of over $700,000 \mathrm{~km}^{2}$ of tropical forest into pasture, together with the phenomenon of global warming, which has registered average increases in temperature from $0.6^{\circ}$ to $0.9^{\circ} \mathrm{C}$ over the last 100 years. As such, the change in climate may lead to other alterations in the environment including the intensification of the global hydrological cycle, which will impact on water resources at a regional level. In fact, differentiated changes of temperature in the atmosphere, the continents and the ocean lead to changes in the pattern of atmospheric pressure and wind. Changes in rainfall patterns are therefore to be expected, in accordance with the mathematical models for global climate forecasting of the Hadley Centre for 2050, which present average reductions of 150 to $250 \mathrm{~mm}$.year in the rainfall of the region.

It is important to note that in the event of intensification in the occurrence of anomalous warming phenomena of the surface temperature of the Pacific and Atlantic oceans, the rains, and therefore the outflows of the rivers, will decrease. In fact, in relation to the Pacific Ocean, the occurrences of El Niño have lead to events of extreme rain deficiency, and consequently, low outflow from the rivers of the region, in particular the north-eastern Amazon. Trends towards drier conditions were observed during El Niño events in 1903, 1912, 1925-26, 198283, 1986-87 and 1997-98. In relation to the Atlantic Ocean, according to the Weather Forecasting and Climate Studies Centre (Centro de Previsão do Tempo e Estudos Climáticos (CPTEC/INPE) and the National Meteorology Institute (INMET), the Sea Surface Temperature was between $0.5^{\circ} \mathrm{C}$ and $1.5^{\circ} \mathrm{C}$ higher in the North Atlantic Ocean from September 2004 to September 2005. In other words, there was persistent abnormal warming. This phenomenon, which was possible responsible for the drought in the Amazon region in 2005, modified the current of humid air mass in the Amazon, principally in important areas of the basins of the following rivers: Rio Solimões, Rio Negro, Rio Madeira, Rio Juruá, amongst others (Freitas [7]).

It is important to highlight that there has been important technical progress in the recent hydroelectric projects in the Amazon Basin, in other words, public and private project developers have taken care to design plants with smaller reservoirs, such as the plants on the River Madeiras de Santo Antônio (3.150 MW) and Jirau (3.300 MW) which have a forecast flooded area of 271 and $258 \mathrm{~km}^{2}$, respectively, (Furnas [9]). Similarly, the Belo Monte plant, situated in the Rio Xingu basin, has a forecast flooded area of approximately $400 \mathrm{~km}^{2}$ and an expected installed capacity of around $7500 \mathrm{MW}$.

Table 1 below sets out the relationship between Reservoir Area/Plant Potency for different power plants. With reservoirs that have lower regulation capacity, however, hydroelectric generation may be vulnerable in years of water shortage. 
Table 1: Hydroelectric plants in the Amazon region- Relation of Reservoir area to Plant Potency. Source: FURNAS [9].

\begin{tabular}{cccc}
\hline $\begin{array}{c}\text { USINAS NA } \\
\text { REGIÃO } \\
\text { AMAZÔNICA }\end{array}$ & $\begin{array}{c}\text { ÁREA DOS } \\
\text { RESERVATÓ } \\
\text { RIOS }\left(\mathbf{k m}^{2}\right)\end{array}$ & $\begin{array}{c}\text { POTÊNCIA } \\
(\mathbf{M W})\end{array}$ & $\begin{array}{c}\text { ÁREA } \\
\text { RESERVATÓRIO/ } \\
\text { POTÊNCIA DA USINA } \\
\left(\mathbf{k m}^{2} / \mathbf{~ M W}\right)\end{array}$ \\
\hline BALBINA & 2.360 & 250 & 9,44 \\
SAMUEL & 584 & 217 & 2,69 \\
MANSO & 387 & 210 & 1,84 \\
TUCURUI & & & \\
1 $^{\mathrm{E}}$ ETAPA & 2.414 & 4.000 & 0,61 \\
2 $^{\mathrm{E}}$ ETAPA & & 8.000 & 0,30 \\
JIRAU & 258 & 3.300 & 0,08 \\
SANTO ANTÔNIO & 271 & 3.150 & 0,086 \\
\hline
\end{tabular}

\section{Measures for the adaptation of the Brazilian hydroelectric system and the use of water to the risks of global climate change}

In closing, we set out suggestions for structural and non-structural actions in hydro-graphic basins and in the management of hydraulic potential, principally in the generation of electricity, taking into account, logically, uncertainties in the forecasting models for flow and the vulnerability of basins and the energy area, and, therefore, of the Brazilian energy matrix, to the risks of climate change.

\subsection{Structural actions}

\subsubsection{Construction / modification of physical infra-structure}

It will be necessary, as soon as possible, to revise the arrangements for hydroelectricity generation at the park that has already been installed, principally in relation to the multiple use of water, either for periods of extreme drought or flooding or in order to guarantee better adaptation to the needs of the increasing population and economic needs of the hydro-graphic basins.

\subsubsection{Removal of reservoir sediments}

Periodic removal of sediment from the reservoir beds is fundamental in order to guarantee greater storage of water and, consequently, maintain a greater energy generating capacity and working life of the plant.

\subsubsection{Transfer of energy and water between hydro graphic basins (regional and continental integration)}

The stimulus of greater continental and regional integration between hydro graphic basins and electricity systems is fundamental. This action may undoubtedly considerably reduce the vulnerability of energy and water supply between countries and consumer markets. 
Nowadays, the operation of the Interlinked Brazilian System guarantees the compensation of seasonal and decennial imbalances between basins and the electric energy market. A drought in the basin of the São Francisco River does not pose greater risks to the consumption of electric energy in the North-eastern region.

On the other hand, continental integration is still at a very early stage, with national political instability restricting the intensification of the exchange of energy between South American countries. The examples of the Brazil-Bolivia Gas Pipeline and the Itaipu Hydroelectric Plant (Brazil and Paraguay) should be perfected in a model of South American integration. Recently, in April 2008, the Brazilian and Argentinean governments reached agreement as to the supply of electricity from Brazil to Argentina during the winter, when there is increased demand for heating, with inverse supply in the summer when there is increased demand for air-conditioning in Brazil.

\subsection{Non-structural action}

\subsubsection{Adaptable management of existing water supply systems}

Structuring supply systems so as to cope with periods of low stock and with the integration of alternative supply systems.

\subsubsection{Changes in operational rules}

The operational rules of the hydroelectric plants need to be revised at times of contingency and be aligned to up to date information as to restrictions on a range of consumptive and non-consumptive use.

\subsubsection{Joint management of atmospheric, superficial and subterranean water}

Water management is moving towards an integrated approach to the hydrographic cycle. In other words, hydro-graphic water basin systems, aquifers and air mass must be taken into consideration in different timescales, but as an integrated whole so as to highlight the potential and restriction on each system. An attempt at integration of the waters of the Prata Basin may be carried out with discussion of the Guarani Aquifer and management of the Air and Water Vapour masses that affect the region, involving Brazil, Bolivia, Paraguay and Uruguay.

\subsubsection{Integration of the operational systems of reservoirs}

There is integration nowadays between several agents in the Brazilian electricity sector for the operation of hydroelectricity generation reservoirs, there is, however, no interaction between these agents and agents of urban and rural supply. Furthermore, the continental interaction of reservoirs is at an early stage, and does not take into account the limitations of the trans-frontier hydro graphic basins such as the Prata Basin and the Amazon River. 


\subsubsection{Increase the time-space coordination of supply and demand of water and energy}

In other words between hydro graphic basins, energy systems, seasonal demand, climate variability and vulnerability.

\section{Conclusions}

In paper, we saw that further warming of the planet, may alter the hydrologic cycle, and, consequently, the regime and hydric availability of the Brazilian hydro graphic basins.

Given the major role of hydro-electric plants in the Brazilian Electricity System, power generation in the country is highly dependent on the hydrologic regimes of the hydro graphic basins.

Conflict over water use and continuing vulnerabilities in the São Francisco, Paraná and Amazonia basins point to the likelihood of increasing challenges for the electricity sector. Changes in the precipitation patterns will require structural and non-structural action aimed at adaptation. The electricity sector has an important role in this process, as it has already acquired considerable knowledge as to the expected inflow into hydroelectric reservoirs and the strong regional influence of this on the availability and use of water resources.

\section{References}

[1] Aceituno, P. (1988). "On the functioning of the Southern Oscillation in the South American Sector: surface climate". Monthly Weather Review, $116,505-524$.

[2] Agência Nacional de Águas - ANA (2002). A Evolução da Gestão de Recursos Hídricos no Brasil. Brasília, 64 p..

[3] Agência Nacional de Águas - ANA (2002b). Overview of Hydrographic Regions in Brazil. Brasília, 85 p..

[4] Agência Nacional de Energia Elétrica - ANEEL (2007). BIG - Banco de Informações de Geração. Brasília.

[5] BRASIL. Ministério de Minas e Energia. Empresa de Pesquisa Energética (2007) Balanço Energético Nacional 2007: Ano base 2006 Relatório final. Rio de Janeiro: EPE, 2007.

[6] Filizola, N., Guyot, J. L., Molinier, M., Guimarães, Oliveira \& Freitas, M. A. V. (2002). "Caracterização Hidrológica da Bacia Amazônica” in Amazônia - Uma Perspectiva Interdisciplinar, Rivas, A. \& Freitas, C. E. (org.), Editora Universidade do Amazonas, Manaus, páginas 33-54.

[7] Freitas, M. A. V. (2006). "Vulnerabilidade Climática e Antrópica dos Recursos Hídricos da Bacia Amazônica”. Nota Técnica do Projeto Gerenciamento integrado e sustentável dos recursos hídricos transfronteiriços na bacia do rio amazonas considerando a variabilidade e as mudanças climáticas - Bolívia, Brasil, Colômbia, Equador, Guiana, Peru, Suriname, Venezuela. Brasília, Projeto GEF Amazonas OTCA/PNUMA/OEA, set., 43 p.. 
[8] Freitas, M. A. V. et al.. (2003). "Hidreletricidade no Brasil: Perspectivas de Desenvolvimento e Sustentabilidade” in O Estado das Águas no Brasil - 2001 - 2002, Freitas, M. A. V. (org.), Agência Nacional de Águas ANA, Ministério do Meio Ambiente, Organização Meteorológica Mundial - OMM, Banco Mundial - BIRD. Brasília, maio de 2003, páginas 49-63.

[9] Furnas Centrais Eletricas S.A. - FURNAS (2005). "RIMA das Usinas Hidrelétricas de Santo Antônio e Jiraú”. Rio de Janeiro, 2005.

[10] Intergovernmental Panel on Climate Change - IPCC (2007). "Climate Change 2007: Impacts, Adaptation and Vulnerability. Contribution of Working Group II to the Fourth Assessment Report of the Intergovernmental Panel on Climate Change", M.L. Parry, O.F. Canziani, J.P. Palutikof, P.J. van der Linden and C.E. Hanson, Eds., Cambridge University Press, Cambridge, UK, 976pp.

[11] Intergovernmental Panel On Climate Change - IPCC (2007b). "Freshwater resources and their management" Cambridge University Press, Cambridge, UK, 155pp.

[12] Marengo J. and S. Hastenrath (1993). "Case studies of the extreme climatic events in the Amazon basin". Journal of Climate, 6, 617-627.

[13] Marengo, J. A. (1995). "Variations and Change in South American Streamflow". Clim. Change, 31, 99-117.

[14] Molinier M., J.L. Guyot, E DE Oliveira and V. Guimarães (1996). Les regimes hydrologiques de l'Amazone et de ses affluents. Hydrologie Tropicale: Geoscience et Outil pour le Developpement, Paris, IAHS PUBL., 238, 209-222.

[15] Molinier M., J. Ronchail, J.L. Guyot, G. Cochonneau, E. De oliveira and V. Guimarães, (2002). "Hydrological variability in the Amazon drainage basin and African tropical basins". Hydrological Processes.

[16] OMM (2004). "Declaracíon de la OMM sobre El Estado del Clima Mundial en 2003". Genebra, OMM- No 966, 12 pp..

[17] Roche, M.A., Fernandez, C., Aliaga, A., Peña, J., Salas, E., Montaño, J.L. (1992). "Balance hídrico de Bolivia". Publ. UNESCO-PHICAB, La Paz, $16 \mathrm{p}$.

[18] ROUCOU, P. (1997). «Impact des températures de surface océanique d'échelle globale sur la dynamique de l'atmosphère et les précipitations tropicales en Amérique du Sud à l'est des Andes: diagnostic et simulation numérique ". Thesis of the Centre de Recherche de Climatologie, ESA5080 CNRS/Université de Bourgogne, France.

[19] Taylor, R. (2008). "The possible role and contribution of hydropower to the mitigation of climate change". Intergovernmental Panel on Climate Change Scoping Meeting on Renewable Energy 20-25 January 2008, Luebeck, Germany.

[20] Tucci, C. E. M.; Silva Dias, P. L.; Clarke, R. T.; Collischonn, W. (2002). "Previsão de médio prazo da afluência de reservatórios com base na previsão climática”. Brasília, Relatório de Pesquisa ANEEL - PNUD MCT, mimeo. 